\title{
PEMULIHAN KESUBURAN SETELAH PEMAKAIAN ALAT KONTRASEPSI PADA WANITA USIA SUBUR DI INDONESIA
}

\section{RETURN OF FERTILITY AFTER CONTRACEPTIVE USE AMONG WOMEN IN CHILDBEARING AGE IN INDONESIA}

\author{
${ }^{1}$ Reni Dwi Setyaningsih, ${ }^{2}$ Siswanto Agus Wilopo, ${ }^{3}$ Ova Emilia \\ ${ }^{1}$ Universitas Harapan Bangsa \\ 2,3Universitas Gadjah Mada
}

Email: reni.dws@gmail.com

\begin{abstract}
ABSTRAK
Isu pengembalian kesuburan setelah penghentian pemakaian alat kontrasepsi merupakan kajian penting dalam studistudi yang berkaitan dengan efikasi dan keamanan dari beragam metode kontrasepsi, baik hormonal maupun non hormonal. Data Survey Demografi dan kesehatan Indonesia tahun 2002-2003 menunjukkan bahwa 34\% wanita usia subur yang berhenti menggunakan kontrasepsi disebabkan karena adanya alasan keinginan untuk hamil kembali. Mekanisme kerja beragam alat kontrasepsi akan berkitan dengan beragam waktu lamanya pemulihan kesuburan pasca pemakaian. Penelitian ini bertujuan untuk melihat berapa lama waktu yang dibutuhkan oleh wanita usia subur pasca berhenti memakai kontrasepsi sampai dengan terjadinya kehamiln berikutnya. Penelitian ini merupakan penelitian observasional dengan menggunakan data sekunder dari data Survei Demografi dan Kesehatan Indonesia tahun 2002-2003. Sampel pada penelitian ini adalah sebanyak 5223 wanita usia subur yang berhenti menggunakan alat kontrasepsi. Event interest pada penelitian ini adalah terjadinya kehamilan setelah berhenti memakai alat kontrasepsi. Penetapan sampel dibatasi pada wanita pernah hamil yang berhenti menggunakan alat kontrasepsi hormonal dan AKDR, yang yang dapat teramati selama periode survey. Hasil penelitian menunjukkan bahwa probabilitas untuk mencapai kehamilan $50 \%$ membutuhkan waktu 7 dan 6 bulan setelah penghentian pemakaian suntik dan implant serta 4 bulan pasca pemakaian pil dan AKDR.
\end{abstract}

Kata Kunci : Kontrasepsi, Pemulihan kesuburan, Wanita usia subur

\section{ABSTRACT}

The issue of return of fertility after discontinuation of contraceptive use is one of the important studies related to the efficacy and safety of various contraceptive methods, both hormonal and non-hormonal. Indonesian Demographic and Health Survey Data from 2002-2003 revealed that 34\% of women in childbearing age who discontinued using the contraceptive was due to pretension to have the next pregnancy. The mechanisms of action for a variety of contraceptives would be related to the varying duration of post-use fertility return. This study was aimed to see how long it takes for women in childbearing age to stop using the contraceptive until the next pregnancy occurs. This study was an observational study using secondary data from the Indonesian Demographic and Health Survey data from 20022003. The samples of this study were 5,223 women in childbearing age who discontinued using the contraceptive. Every interest in this study was the occurrence of pregnancy after stopping using the contraceptive. Determination of the samples was limited to ever pregnant women who stopped using hormonal contraceptive and IUD, which could be observed during the survey period. The results showed that the probability of reaching 50\% pregnancy required 7 and 6 months after the discontinuation of injection and implant use as well as 4 months after pill and IUD use.

Keywords: Contraceptive, Return of fertility, Childbearing Age

\section{PENDAHULUAN}

Pemakaian kontrasepsi merupakan upaya untuk mengontrol jumlah kelahiran yang sejalan dengan konsep making pregnancy safer, yaitu meningkatkan kesehatan ibu dan anak. Hal ini disebabkan karena idealnya kehamilan yang terjadi pada seorang wanita adalah kehamilan yang direncanakan dan pemakaian kontrasepsi merupakan salah satu cara yang dilakukan untuk mengatur kehamilan, sehingga dapat membantu pasangan untuk mengontrol kehamilan sesuai dengan waktu yang direncanakan (Makro, 2003)
Pada umumnya, setiap pasangan yang menggunakan kontrasepsi dilandasi keinginan yang jelas, apakah untuk mengatur jarak kelahiran atau membatasi kelahiran. Kejelasan maksud tersebut terkait dengan tersedianya teknologi kontrasepsi sesuai dengan keamanan medis serta kemungkinan kembalinya fase kesuburan, efektivitas, dan efisiensi metode kontrasepsi.

Isu pengembalian kesuburan setelah penghentian pemakaian alat kontrasepsi merupakan kajian penting dalam studi-studi yang berkaitan dengan efikasi dan keamanan 
dari beragam metode kontrasepsi, baik hormonal maupun non hormonal.

Pemakaian kontrasepsi menjadi salah satu faktor yang dapat mempengaruhi kemampuan wanita untuk hamil. Kemampuan untuk menjadi hamil kembali/ pengembalian kesuburan setelah penggunaan alat kontrasepsi dihentikan, kecuali untuk kontrasepsi mantap, merupakan salah satu syarat metode kontrasepsi yang ideal. Tanpa pemakaian kontrasespi, pada umumnya $90 \%$ pasangan akan menjadi hamil dengan melakukan hubungan sexual yang rutin dalam satu tahun dan meningkat menjadi 95\% setelah dua tahun. Artinya 5-10 persen pasangan subur membutuhkan waktu lebih dari satu tahun untuk mampu menjadi hamil (Cahill, D.J. and Wardle, 2002)

Beragam penelitian menunjukkan adanya beragam waktu pemulihan kesuburan setelah pemakaian alat kontrasepsi. Sebuah meta analisis yang dilakukan oleh Girum \& Wasie tahun 2019 menemukan bahwa persentase terjadinya kehamilan pada 12 bulan pertama pasca pemakaian kontrasepsi adalah sebesar $87 \% \quad(95 \% \mathrm{Cl}: 78.2 \%-88 \%)$ (Tadele Girum, 2018)

Jenis - jenis alat kontrasepsi baik yang sifatnya hormonal (pil, suntk, implant) dan non hormonal (IUD / AKDR) menunjukkan beragam hasil yang berbeda terkait dengan pemulihan kesuburan pasca penghentian. Akan tetapi lamanya waktu pemulihan kesuburan tersebut sebenarnya tidak terkait dengan gangguan kesuburan yang bersifat permanen. Hal ini dikaitan dengan kandungan hormon pada masingmasing jenis alat kontrasepsi dan faktor lain yang terkait dengan kesuburan perempuan, antara lain adalah faktor usia, riwayat abortus sebelumya, kebiasaan merokok dan lain-lain.

Beragamnya waktu pemulihan kesuburan pasca penghentian kontrasepsi ini adalah hal yang menariku ntuk dikaji berkaitan dengan adanya keinginan untuk hamil kembali pasca berhenti memakai alat kontrasepsi. Hasil riset Survei Demografi dan Kesehatan Indonesia (SDKI) menunjukkan bahwa $34 \%$ wanita yang berhenti menggunakan alat kontrasepsi adalaha disebabkan karena alasan keinginan hamil kembali (SDKI 2002-2003). Hal tersebut membuktikan pentingnya keterjaminan bahwa pemakaian kontrasepsi tidak menyebabkan kegagalan kesuburan secara permanen. Hal ini tentu saja penting menjadi perhatian bagi para wanita usia subur termasuk juga bagi petugas kesehatan untuk dapat mempertimbangkan banyak faktor dalam pemilihan alat kontrasepsi yang tepat bagi wanita usia subur dikaitan dengan beberapa faktor lain diluar pemakaian kontrasepsi itu sendiri.

Berdasarkan latar belakang tersebut, penelitian ini bertujuan untuk mengetahui berapa lama waktu yang dibutuhkan untuk terjadinya kehamilan pasca penghentian pemakaian alat kontrasepsi.

\section{METODE}

Penelitian ini merupakan penelitian observasional analitik dengan menggunakan data sekunder dari Survei Demografi dan Kesehatan Indonesia (SDKI) tahun 20022003.

Analisis diawali dengan melakukan proses seleksi terhadap wanita yang pernah hamil, pernah menggunakan alat kontrasepsi dan berstatus kawin pada saat berhenti atau pada saat tidak memakai alat kontrasepsi. Adapun yang menjadi event yang diamati dalam penelitian ini adalah terjadinya kehamilan setelah berhenti memakai alat kontrasepsi.

Penetapan sampel dibatasi pada wanita yang berhenti menggunakan alat kontrasepsi hormonal dan AKDR, yang yang dapat teramati selama periode survey. Besar sampel dalam penelitian ini adalah sebanyak 5.223 orang. Prosedur seleksi yang dilakukan ditunjukkan pada gambar 2 .

\section{HASIL DAN PEMBAHASAN}

Survei Demografi dan Kesehatan Indonesia (SDKI) 2002-2003 merupakan survei tingkat nasional yang dilakukan pada 29.483 wanita pernah kawin berusia 15-49 tahun dan 8.310 pria berstatus kawin berusia 15-54 tahun. Tujuan utama SDKI 2002-2003 adalah untuk menyediakan informasi yang rinci tentang kesehatan ibu dan anak, kematian anak-anak dan dewasa, pengetahuan dan sikap mengenai HIVIAIDS dan penyakit menular seksual lainnya serta informasi tentang fertilitas dan keluarga berencana (Makro, 2003)

Subjek pada penelitian ini adalah wanita usia subur yang berusia 15-49 tahun yang pernah hamil dan berstatus kawin serta pernah menggunakan alat kontrasepsi hormonal dan AKDR serta berhenti memakai alat kontrasepsi hormonal dan AKDR dalam periode survey tahun 1997-2002.

Hasil SDKI 2002-2003 menunjukkan bahwa $57 \%$ wanita pernah kawin sedang 
menggunakan kontrasepsi dan 54 persennya menggunakan metode modern. Diantara cara modern, alat kontrasepsi yang paling banyak dipakai adalah suntik dan pil, masing-masing sebesar 26 dan 13 persen. Sebaran masingmasing jenis kontrasepsi secara lengkap disajikan pada Gambar 1.

Alasan berhenti memakai alat kontrasepsi yang paling banyak dijumpai adalah keinginan untuk hamil kembali yaitu sebesar $34 \%$ dan alasan tersebut berlaku untuk semua alat/ cara KB, kecuali pada pemakai alat/ cara KB kondom dan metode amenore laktasi (MAL). Keinginan untuk hamil setelah berhenti memakai alat kontrasepsi sebagian besar dilakukan oleh ibu yang menggunakan alat kontrasepsi pil yaitu sebesar $35,6 \%$.

Perbandingan waktu menjadi hamil kembali pada 15.228 wanita usia subur berstatus kawin yang memiliki riwayat hamil sebelumnya, yang dikelompokkan berdasarkan riwayat pemakaian alat kontrasepsi yaitu hormonal, AKDR dan tidak memakai alat kontrasepsi secara lengkap disajikaan pada gambar 3. Hasil analisis menunjukkan bahwa terdapat perbedaan yang berarti pada ketiga kelompok adalah pemakai AKDR, hormonal dan yang tidak memakai alat kontrasepsi pada saat probabilitas untuk terjadi kehamilan mencapai $50 \%$, masing-masing adalah 12,6 dan 4 bulan.

Perbandingan pemulihan kesuburan yang dilihat berdasarkan lamanya waktu menjadi hamil kembali pasca penghentian pemakaian alat kontrasepsi pil, suntik, implant dan AKDR. Hasil analisis menunjukkan bahwa probabilitas untuk mencapai kehamilan sebesar $50 \%$ membutuhkan waktu 7 dan 6 bulan setelah penghentian pemakaian suntik dan implant dan 4 bulan pasca pemakaian pil dan AKDR.

Terdapat beberapa studi tentang tertundanya pemulihan kembali kesuburan setelah penghentian pemakaian kontrasepsi pil. Penelitian yang dilakukan oleh Cronin, et al pada tahun 2009 di Eropa mendapatkan hasil bahwa pemakaian kontrasepsi oral tidak memberikan pengaruh terhadap kehamilan, akan tetapi lebih pada faktor usia yang berperan besar dalam terjadinya kehamilan. Studi dilakukan dengan dengan melacak hampir 60.000 pengguna kontrasepsi oral didapatkan sebanyak $20 \%$ responden mencapai kehamilan pada siklus pertama setelah penghentian dan sisanya sebanyak
$80 \%$ terjadi kehamilan pada satu tahun pasca penghentian, tanpa melihat jenis kontrasepsi oral yang digunakan sebelumnya. Data tersebut sebanding dengan wanita yang ingin hamil tetapi tidak menggunakan kontrasepsi oral, dimana faktor usia sebenarnya memberikan kontribusi penting dalam terjadinya kehamilan. Secara alami akan terjadi penambahan usia pada saat wanita menghentikan menggunakan alat kontrasepsi dibandingkan pada asaat awal memulai pemakaian (Maureen Cronin, Ilka Schellschmidt, 2009).

Lama pemakaian kontrasepsi pil pada beberapa studi menunjukkan bahwa tidak terdapat trend yang signifikan berkaitan dengan peningkatan risiko dengan lama pemakaian kontrasepsi oral. Pada $88 \%$ wanita yang belum pernah hamil sebelumnya melaporkan terjadinya kehamilan dalam waktu kurang dari 4 tahun. Hal ini mengindikasikan bahwa tidak adanya kegagalan fertilitas secara absolut setelah penghentian pemakaian kontrasepsi pil (Farrow A., Hull M. G.R., Northstone K., Taylor H., 2002)

Pemulihan kesuburan pada wanita pasca penghentian pemakaian implant, pemulihan kesuburan akan terjadi dengan segera setelah penghentian pemakaian. Implant mengeluarkan progesteron dalam dosis kecil yang akan segera habis saat implant dilepas dan sebagai akibatnya ovarium akan kembali berfungsi normal (Croxatto, 2002). Hal tersebut menunjukkan bahwa pemakaian kontrasepsi implant tidak memilki risiko yang terkait dengan lamanya pemulihan kesuburan pada wanita. Hasil penelitian menunjukkan adanya pregnancy rates yang tidak berbeda dengan penghentian metode kontrasepi yang lain, yaitu sebesar 76-100 persen dalam waktu satu tahun setelah pelepasan implant (Glassier, 2002; Diaz, S., Pavez, M., Miranda, P., Robertston, D.N., Sivin, I. and Croxatto, 1982); Sivin, I., Sanchez, F.A., Diaz, S. and Robertson, 1983).

Affandi, et al (1987) melakukan pengamatan secara prospektif terhadap 51 wanita di Indonesia dan didapatkan hasil bahwa tidak ditemukan adanya perbedaan pregnancy rates pada wanita yang berhenti menggunakan alat kontrasepsi AKDR dan DMPA. Sebesar $76 \%$ wanita yang pernah menggunakan norplant terjadi kehamilan dalam waktu 12 bulan dan $90 \%$ kehamilan terjadi dalam waktu 2 tahun (Affandi, B., 
Santoso S.S., Djajadilaga, Hadisaputra, W. and Moeloek, 1987).

Penundaan pemulihan kesuburan hanya menjadi masalah bagi pemakai kontrasepsi suntik DMPA, yang mungkin mengalami interval berkepanjangan sebelum ovulasi normal menjadi pulih kembali. Penundaan ini mungkin disebabkan oleh menetapnya DMPA dalam sirkulasi, karena mikrokristal di depot yang disuntikkan tersebut kadang-kadang larut sangat lambat. Penundaan pemulihan kesuburan rata-rata berlangsung 7 sampai 8 bulan setelah perhitungan efek 3-4 bulan dari suntikan terakhir. Hal ini berarti bahwa sebagian wanita akan memerlukan waktu lebih dari setahun untuk dapat hamil. Studi yang dilakukan oleh Schwallie and Assenjo (1974) didapatkan bahwa DMPA menghambat pelepasan luteinizing hormone (LH), mencegah ovulasi tanpa menekan sekresi FSH (follicle stimulating hormone). Rata-rata waktu yang dibutuhkan terjadinya ovulasi yang pertama yang diukur oleh kadar serum progesteron pada fase luteal adalah 211,1 hari. Atas dasar hal tersebut DMPA memiliki efek kontrasepsi yang berkepanjangan. Pada $68 \%$ wanita yang berhenti menggunakan DMPA akan terjadi kehamilan dalam 12 bulan, $83 \%$ akan hamil dalam 15 bulan dan 93\% menjadi hamil dalam waktu 18 bulan setelah penyuntikan terakhir (Shulman Lee P., 2006).

Studi komparatif diantara pengguna beragam metode kontrasepsi ditemukan bahwa rata-rata waktu menjadi hamil pada pengguna DMPA dalam waktu 2-4 tahun membutuhkan waktu yang lebih panjang untuk terjadinya kehamilan dibandingkan dengan pengguna DMPA dalam waktu 1-2 tahun (Hassan, M.A., 2004). Penundaan pemulihan kesuburan yang terjadi tidak menyebabkan kegagalan yang bersifat permanen, hal ini ditunjukan dengan kejadian kehamilan yang dijumpai tidak berbeda antara pengguna DMPA dan AKDR (Pardthaisong, T., Gray, 1980). Meskipun tidak terjadi kegagalan pemulihan kesuburan secara permanen setelah penghentian pemakaian DMPA akan tetapi terdapat penundaan selama 6-10 bulan untuk menjadi subur kembali dan waktu untuk terjadinya konsepsi pada beberapa wanita dapat tertunda sampai dengan 2 tahun (Shulman Lee P., 2006).

AKDR umumnya sangat mudah dikeluarkan dan pemulihan kesuburan berlangsung cepat (angka konsepsi 78-88 persen setelah 12 bulan dan 92-97 persen pada 3 tahun setelah pengeluaran).
Penundaan pemulihan kesuburan pada pemakai AKDR, dihubungkan dengan adanya risiko terjadinya penyakit radang panggul. Hal ini berkaitan dengan masuknya organisme infektif ke dalam rongga rahim saat pemasangan AKDR terutama apabila wanita mengidap infeksi yang tidak terdeteksi atau pemasang tidak mengikuti prosedur aseptik yang benar. Walaupun AKDR itu sendiri tidak menyebabkan infeksi panggul, namun perilaku seksual wanita pemakai dan pasangannya dapat meningkatkan risiko timbulnya infeksi menular seksual dan dapat menyebabkan infeksi panggul. Kerusakan tuba yang diikuti oleh infertilitas merupakan konsekuensi serius dari infeksi panggul pada wanita.

Pada wanita yang belum pernah hamil yang menggunakan AKDR, pada periode waktu yang lama, akan dihadapkan pada risiko penurunan kesuburan. Hal ini sesuai dengan penelitian Doll and Vessey (2001), bahwa $35 \%$ wanita nulipara yang berhenti menggunakan AKDR membutuhkan waktu 12 bulan sampai terjadi kehamilan berikutnya dibandingkan dengan $54 \%$ wanita yang menggunakan metode kontrasepsi yang lain. Infeksi Merupakan komplikasi yang paling serius yang berhubungan dengan pemakaian AKDR. Jenis infeksi yang terjadi adalah Penyakit Radang Panggul (PRP) (Doll, H., Vessey, M. and Painter, 2001).

Angka PRP keseluruhan pada pemakai AKDR adalah sekitar 1,4 sampai 1,6 kasus per 1000 wanita selama tahun pemakaian, yaitu dua kali lipat dibandingkan dengan wanita yang tidak menggunakan kontrasepsi. Hubungan antara pemakaian kontrasepsi AKDR dengan penyakit radang panggul adalah hal yang masih kontroversial. Hasil meta analisis pada 36 studi menunjukkan bahwa relative risk untuk terjadinya penyakit radang panggul pada wanita adalah sebesar 3,3 (Gareen, I.F., Greenland, S. and Morgenstern, 2002).

Seiring dengan peningkatan ketersediaan dan pemanfaatan kontrasepsi, hal tersebut juga penting untuk ditegaskan efek penggunaan kontrasepsi pada kembalinya kesuburan setelah penghentian Namun saat ini bukti pada kembalinya kesuburan setelah penggunaan kontrasepsi tidak meyakinkan dan praktis kesuburan setelah penghentian kontrasepsi tetap menjadi perhatian besar bagi wanita yang menggunakan kontrasepsi. Ketakutan ini menimbulkan dampak negatif pada pemanfaatan dan kelanjutan kontrasepsi. Oleh karena itu, Memperkirakan Laju 
Kembalinya Kehamilan Setelah Penggunaan Kontrasepsi dari laporan yang tersedia dan mengidentifikasi faktor-faktor yang terkait penting untuk merancang strategi untuk mengatasi masalah (Tadele Girum, 2018)

\section{KESIMPULAN}

Median waktu untuk terjadi kehamilan pada kelompok wanita usia subur yang tidak pernah memakai alat kontrasepsi, pernah memakai hormonal dan pernah memakai AKDR masing-masing adalah 12, 6 dan 4 bulan. Probabilitas untuk terjadi kehamilan mencapai 50\%, masing-masing adalah 7 dan 6 bulan pada pemakai suntik dan implan serta 4 bulan pada pemakai pil dan AKDR.

\section{SARAN}

Komunikasi, informasi dan edukasi serta konseling pada wanita usia subur calon akseptor KB menjadi hal penting yang perlu diberikan secara detil tentang pemulihan kesuburan pasca pemakaian kontrasepsi berkaitan dengan faktor usia maupun jenis pilihan alat kontrasepsi. Penelitian lebih lanjut perlu dilakukan tentang pengaruh pemakaian beragam jensi alat kontrasepsi, serta berapa lama waktu ideal bagi wanita usia subur untuk merencanakan kehamilan pasca pemakaian alat kontrasepsi dengan mempertimbangkan variabel yang berperan dalam kesuburan wanita.

\section{REFERENSI}

Affandi, B., Santoso S.S., Djajadilaga, Hadisaputra, W. and Moeloek, F. . (1987). Pregnancy after removal of norplant implants contraceptive, 36 , 203-209.

Cahill, D.J. and Wardle, P. . (2002). Management of infertility. British Medical Journal, 325, 28-32.

Croxatto, H. . (2002). Mechanism that explain the contraceptive action of progestin implant for women. Clin Obstet Gynecol, 41(4), 958-965.

Diaz, S., Pavez, M., Miranda, P., Robertston, D.N., Sivin, I. and Croxatto, H. B. (1982). A five year clinical trial of levonorgestrol silastic implants (NorplantTM). Contraception, 25, 447-456.

Doll, H., Vessey, M. and Painter, R. (2001). Return of fertility in nulliparous women after discontinuation of the intrauterine device: Comparison with women discontinuing other methods of contraception. Br J Obstet Gynaecol, 108, 304-314.
Farrow A., Hull M. G.R., Northstone K., Taylor H., F. W. C. L. and G. J. (2002). Prolonged use of oral contraception before a planned pregnancy is associated with a decreased risk of delayed conception. Hum Reprod, 17(10), 2754-2761.

Gareen, I.F., Greenland, S. and Morgenstern, H. (2002). Intrauterine devices and pelvic inflamatory disease: Metaanalysis of published studies 1974-1990. Epidemiology, 11(589-597).

Glassier, A. (2002). Implantable contraception for women : effectiveness, discontinuation rates, return of fertility and outcome of pregnancies. Contraception, 65, 29-37.

Hassan, M.A., and K. S. . (2004). Is previous use of hormonal contraception associated with a detrimental effect on subsequent fecundity? European Society of Human Reproduction and Embryology, 19 (2), 344-351.

Makro, B. P. S. and O. (2003). Survei Demografi dan Kesehatan Indonesia.

Maureen Cronin, Ilka Schellschmidt, J. D. (2009). Rate of pregnancy after using drospirenone and other progestincontaining oral contraceptives. Obstetry Abd Gynecology, 114(3), 616-622.

Pardthaisong, T., Gray, R. H. and M. E. . (1980). Return of fertility after discontinuation of depot medroxyprogesterone acetate and intrauterine devices in Northern Thailand. Lancet, 1, 509-512.

Shulman Lee P., and W. C. L. (2006). Return to fertility after use of reversible contraception. Dialogues in Contraception, (10), 11.

Sivin, I., Sanchez, F.A., Diaz, S. and Robertson, D. . (1983). A four-year clinical study of norplant implants. Stud Fam. Plann, 14, 184-191.

Tadele Girum, A. W. (2018). Return of fertility after discontinuation of contraception: a systematic review and meta-analysis. Contraception and Reproductive Medicine, 3, 1-9. 


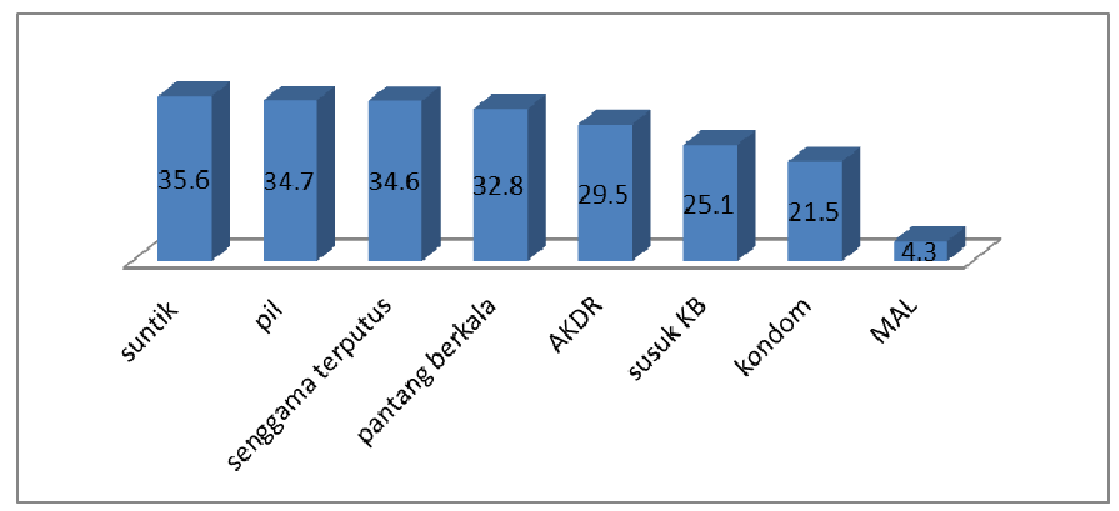

Gambar 1. Persentase Wanita yang Berhenti Memakai Alat Kontrasepsi Berdasarkan Alasan Ingin Hamil Menurut Metode tertentu 


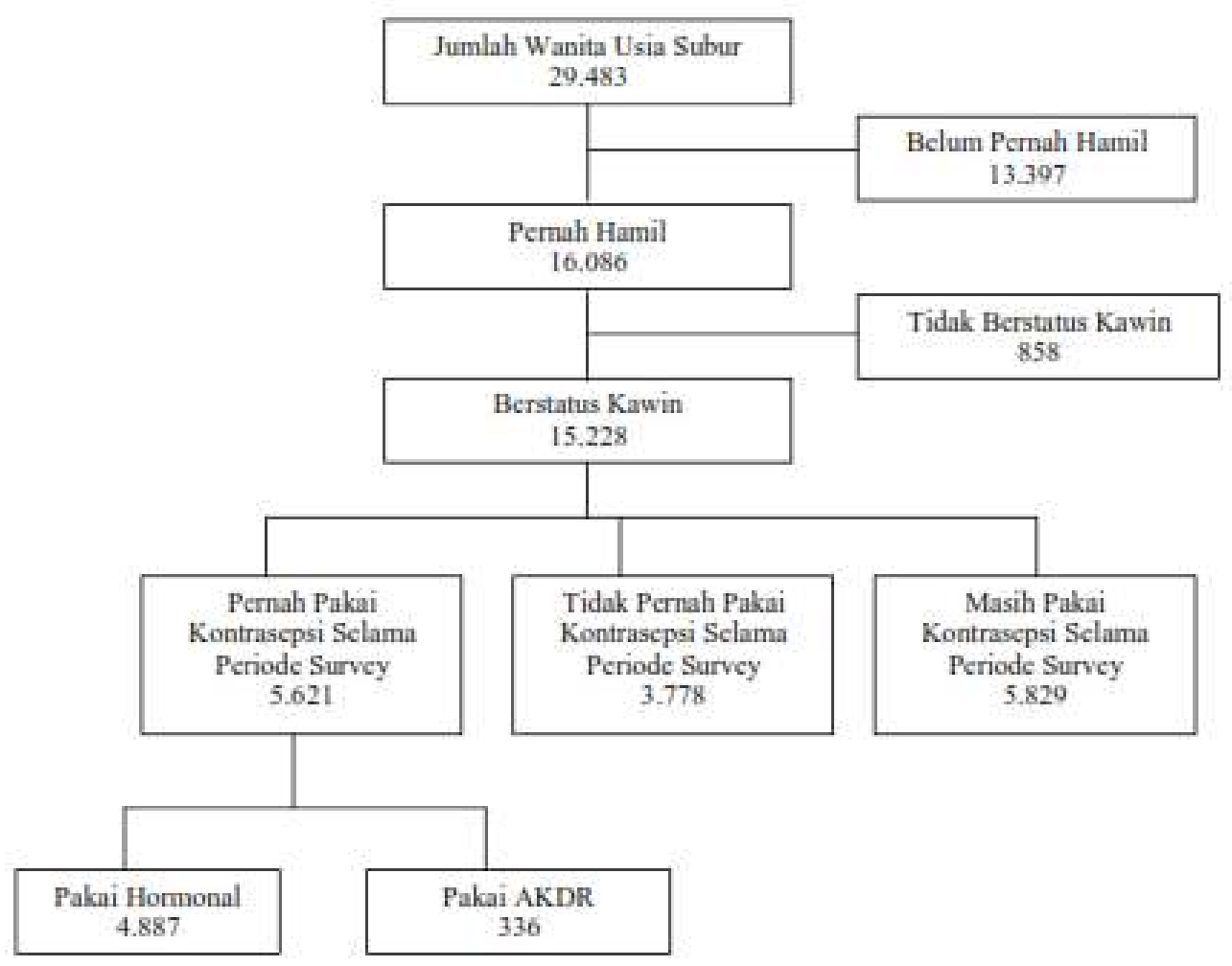

Gambar 2. Prosedur Seleksi Sampel Penelitian

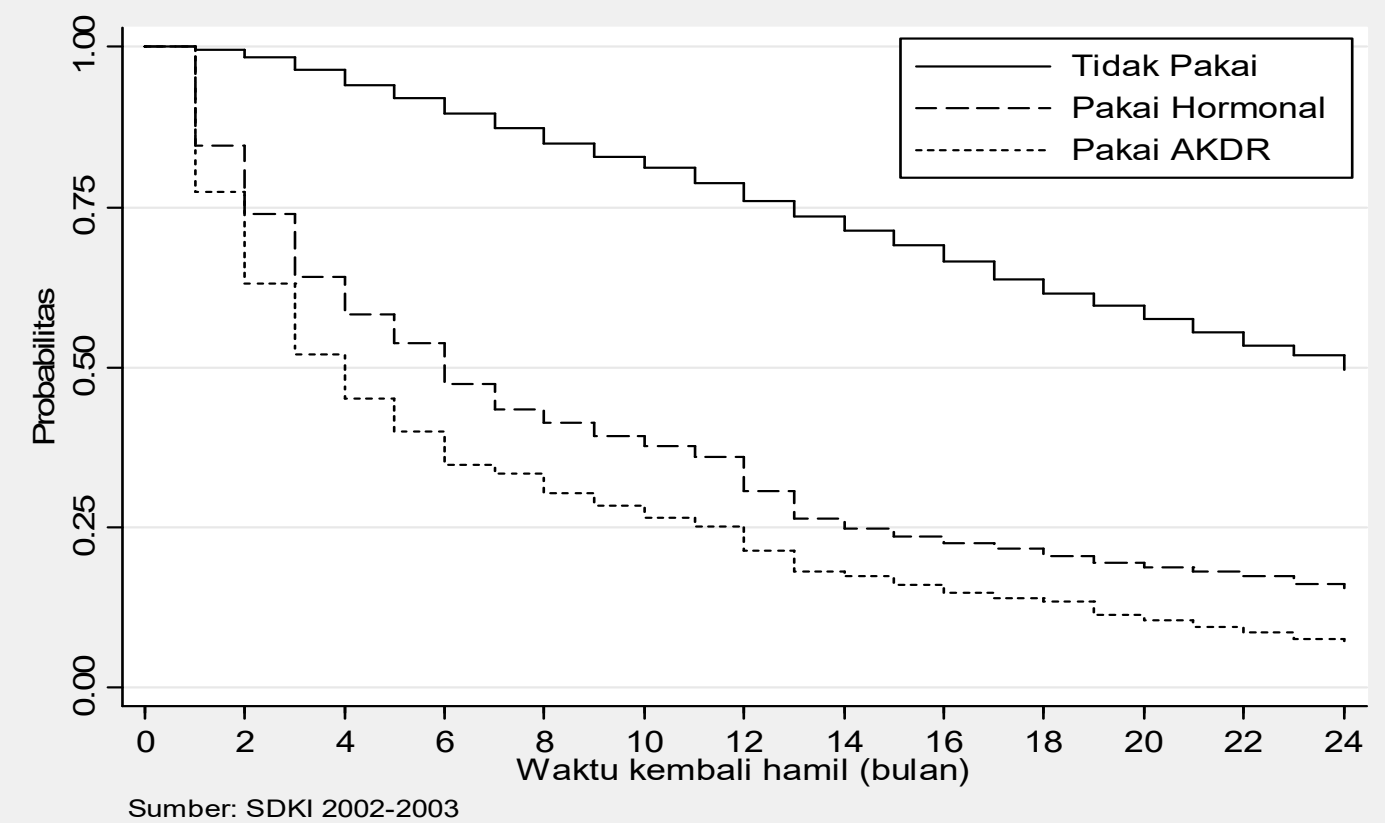

Gambar 3. Distribusi Waktu menjadi Hamil Berdasarkan Riwayat Pemakaian Kontrasepsi 


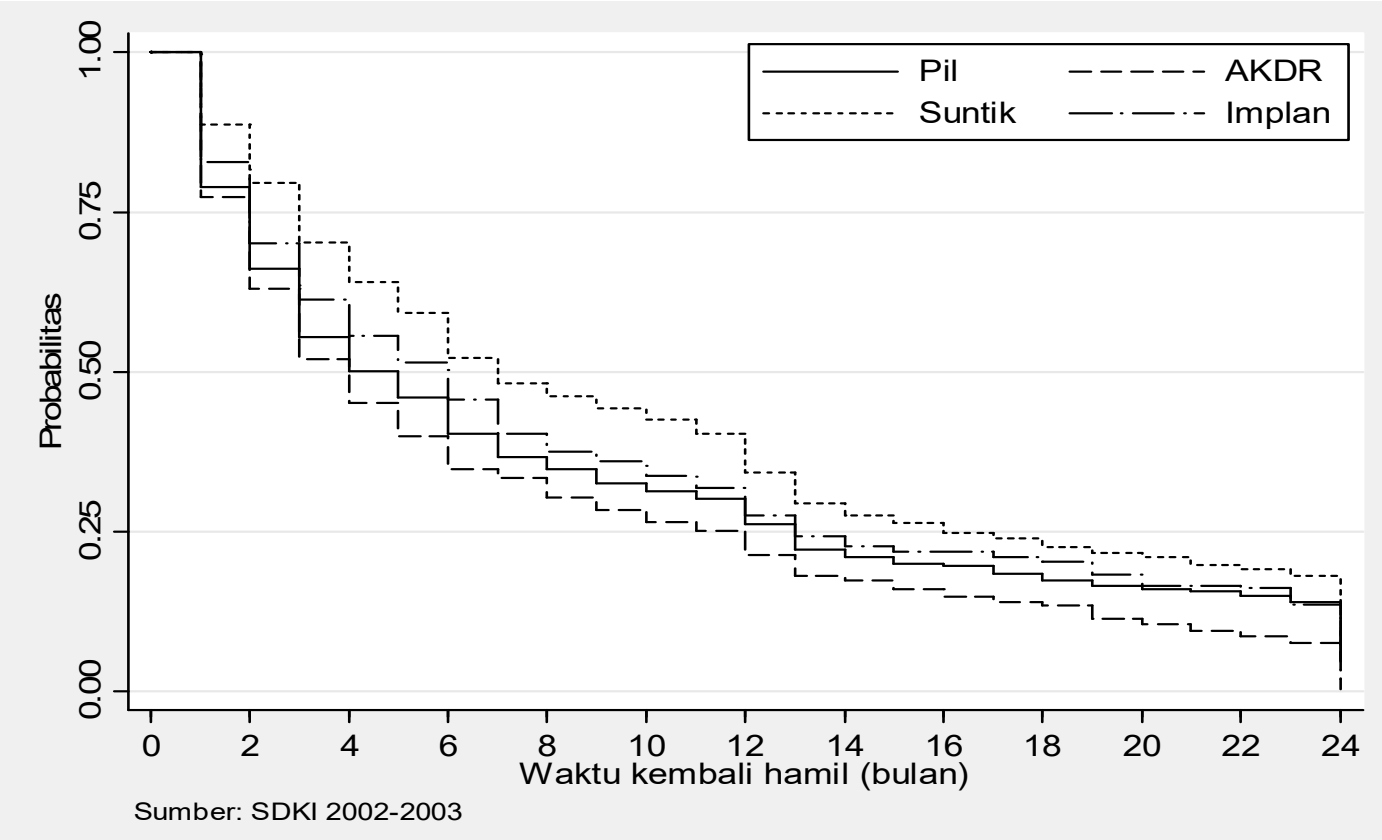

Gambar 4. Distribusi Waktu menjadi Hamil Berdasarkan Riwayat Pemakaian Beragam Jenis Alat Kontrasepsi 